\title{
EVALUATING THE ESSENTIAL AND NON-ESSENTIAL METAL REMEDIATION EFFICIENCY OF Chlorella vulgaris, AND PHOTOSYNTHETIC GENE EXPRESSION LEVEL CHANGES DURING THE PROCESS
}

\author{
Tuğba Şentürk ${ }^{1}$, Muhammet Burak Batır ${ }^{1}$ (D), Çisil Çamlı ${ }^{(\mathbb{D})}$, Şükran Yıldız $^{1}$ (D)
}

Cite this article as:

Şentürk, T., Batır, M.B., Çamlı, C., Yıldız, Ş. (2019). Evaluating the essential and non-essential metal remediation efficiency of Chlorella vulgaris, and photosynthetic gene expression level changes during the process. Aquatic Research, 2(3), 134-142. https://doi.org/10.3153/AR19011

\section{${ }^{1}$ Manisa Celal Bayar University, Faculty of Science and Art Department of Biology, Manisa, Turkey \\ ${ }^{2}$ Manisa Celal Bayar University, Applied Science Research Center, Manisa, Turkey}

ORCID IDs of the author(s): T.Ş. 0000-0002-9882-0079 M.B.B. $0000-0002-8722-5055$ C.Ç. 0000-0002-9641-7219 Ş.Y. 0000-0003-3195-2269

Submitted: 15.04 .2019

Revision requested: 09.05.2019

Last revision received: 18.05 .2019

Accepted: 20.05.2019

Published online: 26.05 .2019

Correspondence:

Tuğba ŞENTÜRK

E-mail: tugba sen34@hotmail.com

\begin{abstract}
Algal populations hold great potential for encountering water pollution problem due to their remediation abilities. Thus, using them for removing the pollutants stands as a powerful approach. However, it is crucial to investigate the negative effects of these pollutants on algal populations as well as understanding the removal capacity of these populations in order to benefit their abilities. In the present study, Chlorella vulgaris was used as a candidate for metal removal. Besides the remediation capacity for certain essential $\left(\mathrm{Cu}^{2+}, \mathrm{Zn}^{2+}, \mathrm{Co}^{2+}, \mathrm{Mn}^{2+}, \mathrm{Mo}^{6+}\right)$ and non-essential $\left(\mathrm{Cd}^{2+}\right.$, $\mathrm{Pb}^{2+}, \mathrm{Sn}^{4+}, \mathrm{Ba}^{2+}, \mathrm{As}^{5+}$ ) metals, chlorophyll and carbohydrate contents, and photosynthetic gene (psaB, Photosystem I reaction center protein subunit B) expression levels were also evaluated. Results indicated that remediation efficiency of $C$. vulgaris for essential metals was $\mathrm{Cu}>\mathrm{Co}>\mathrm{Zn}>\mathrm{Mo}>\mathrm{Mn}$ and for non-essential metals was $\mathrm{Sn}>\mathrm{Pb}>\mathrm{Ba}>\mathrm{Cd}>\mathrm{As}$, respectively. It was also observed that psaB expression was increased after the essential and non-essential metal treatment. It can be concluded that $C$. vulgaris can be used as a bioindicator for Mn and As while it is also suitable to be used for metal removal.
\end{abstract}

Keywords: Bioremediation, Phytoremediation, Metal pollution, Metal removal, Algal removal

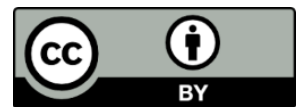

CC Copyright 2019 by ScientificWebJournals Available online at http://aquatres.scientificwebjournals.com 


\section{Introduction}

In recent years, most of the available water resources are facing metal pollution. Metals are one of the significant pollutants of the water ecosystems. The main reason for this problem is the increased industrial discharge due to the increased human population. The negative effects of metal pollution are specifically crucial for algal populations. Metal pollution caused by the human activities accelerate the toxicity of water organisms. Since they are the primary producers of water ecosystems, changes in their vitally would cause changes in other living organisms vital rates as well (Franklin et al., 2000). Thus, it is critical to balance the metal discharge levels in non-toxic levels.

Metals can be a group as essential and non-essential based on the levels of metabolic usage. Non-essential metals for algae, like $\mathrm{Cd}, \mathrm{Pb}, \mathrm{As}$, and $\mathrm{Hg}$, cause toxicity even in low doses, while essential metals like $\mathrm{Cu}, \mathrm{Zn}$, and $\mathrm{Mn}$ are necessary for metabolic activities, yet they also show toxicity in high doses (Provasoli, 1958).

Although the negative effects of metal pollution on algal populations have been studied widely, the use of algae as bio-indicators, their effect of self-purification as a result of oxygen production, as well as their waste removal effect have been also shown in several studies (Islam et al., 2007; Khan et al., 2008; Wang \& Chen, 2009; Hong et al., 2011; Kumar et al., 2015; König-Peter et al., 2015). Based on these properties, extensive and detailed studies in these fields, specifically on the negative effects of pollution and the removal capacity of algae would help to benefit algae more efficiently for pollutant removal in the future (Mehta \& Gaur, 2005). Chlorella vulgaris, as a cosmopolitan species, carry a significant potential for this purpose.

The aim of this study is to evaluate and compare the essential $\left(\mathrm{Cu}^{2+}, \mathrm{Zn}^{2+}, \mathrm{Co}^{2+}, \mathrm{Mn}^{2+}, \mathrm{Mo}^{6+}\right)$ and non-essential $\left(\mathrm{Cd}^{2+}\right.$, $\left.\mathrm{Pb}^{2+}, \mathrm{Sn}^{4+}, \mathrm{Ba}^{2+}, \mathrm{As}^{5+}\right)$ removal and adsorption capacity of $C$. vulgaris, observe the changes in chlorophyll-a (chl-a), chlorophyll-b (chl-b) and carbohydrate content, as well as the photosynthetic gene (psaB, Photosystem I reaction center protein subunit B) expression levels.

\section{Material and Methods}

\section{Algal Culture Growth and Preparation}

C. vulgaris was obtained from the Culture Collection of Microalgae at the University of Ege, Izmir, Turkey. A standard initial inoculum of the algae was inoculated to culture flasks (200 mL each) that contained BG-11 Medium (Stanier et al., $1979)$, and incubated at $28 \pm 1^{\circ} \mathrm{C}$ under $12 \mathrm{~h}$ light $\left(20 \mathrm{E} \mathrm{m}^{-2}\right.$ $\mathrm{s}^{-1} \pm 20 \%$ ), with magnetic stirring $(100 \mathrm{rpm})$. The $\mathrm{pH}$ value was adjusted to 6-6.5 using $1 \mathrm{M} \mathrm{NaOH}$ and $1 \mathrm{M} \mathrm{HCI}$. The metal removing capacities of the $C$. vulgaris was determined using $50 \mathrm{ml}$ aliquots of ten-day-old bacterial cultures, when they were in the linear phase of growth (De Philippis et al., 2007). $5 \mathrm{~mL}$ algae were filtered from $0.45 \mu \mathrm{m}$ Whatman $\mathrm{GF} / \mathrm{C}$ filters, oven dried for $3-4 \mathrm{~h}$ at $105^{\circ} \mathrm{C}$ and weighted in order to calculate dry weight was as $\mathrm{mg} / \mathrm{mL}$.

\section{Metal Solution Preparation}

Metal solutions was prepared for the essential metals $\left(\mathrm{Cu}^{2+}\right.$, $\left.\mathrm{Zn}^{2+}, \mathrm{Co}^{2+}, \mathrm{Mn}^{2+}, \mathrm{Mo}^{6+}\right)$ and non-essential $\left(\mathrm{Cd}^{2+}, \mathrm{Pb}^{2+}, \mathrm{Sn}^{4+}\right.$, $\mathrm{Ba}^{2+}, \mathrm{As}^{5+}$ ) for 5 different concentrations as $0.5 ; 1 ; 2.5 ; 5$ and $10 \mathrm{mg} / \mathrm{L}$ (De Philippis et al., 2007). Another metal mix solution containing both essential and non-essential metals was also prepared with same concentrations. By using these metal solutions algal culture was treated for 10 days.

\section{Chlorophyll and Carbohydrate Content}

Total carbohydrate contents were determined by using the phenol-sulfuric acid assay and using glucose as a standard. $1 \mathrm{~mL}$ culture aliquots were used for spectrophotometrically quantification of the total carbohydrate content by the phenol-sulfuric acid assay (Skoog et al., 2000).

In order to measure the chlorophyll content, $10 \mathrm{~mL}$ samples of each culture were collected. Acetone and magnesium carbonate were used to extract the chlorophyll from the samples. According to the method of Parsons and Strickland (1963), chl-a and chl-b contents were measured spectrophotometrically.

\section{ICP Analysis}

Supernatants collected from the samples after metal treatment were analyzed in ICP-MS (Agilent 7700 Series, US) with 3 replicates. Metal removal amount (q, given as $\mathrm{mg} / \mathrm{g}$ ) and metal removal percentage was calculated as follows (König-Peter et al., 2015);

$$
\begin{aligned}
& \mathrm{q}(\mathrm{mg} / \mathrm{mL})=\left(\mathrm{c}_{\mathrm{i}}-\mathrm{c}_{\mathrm{t}}\right) * \mathrm{~V} / \mathrm{m} \\
& \text { Metal removal } \%=100 *\left(\mathrm{c}_{\mathrm{i}}-\mathrm{c}_{\mathrm{t}}\right) / \mathrm{c}_{\mathrm{i}} \\
& \mathrm{V} \text { : solution volume }(\mathrm{mL}) \\
& \mathrm{m} \text { : dry weight of the adsorbent }(\mathrm{g}) \\
& \mathrm{c}_{\mathrm{i}} \text { and } \mathrm{c}_{\mathrm{t}} \text { : initial and final metal concentrations }
\end{aligned}
$$

\section{Gene Expression Analysis}

Total RNA Miniprep Kit (GMbiolab Co. Ltd., Taiwan) was used for RNA isolation. RNA quality and integrity were observed by bleach agarose with SAFE-T stain (Aranda et al., 2012). cDNA synthesis was performed via cDNA Reverse 
Transcription Kit (AppliedBiosystems). With the aim of keeping the expression levels equal for each sample, RNA amount was fixed to $9 \mathrm{ng} / \mu \mathrm{L}$.

In order to determine the expression levels of $18 \mathrm{~S}$ rRNA (housekeeping gene) and psaB (Photosystem I reaction center protein subunit B) with RT-PCR, 18S rRNA and psaB sequences were determined from the National Center for Biotechnology Information (NCBI) database. Based on this, specific primers were designed with Primer3Plus software (Table 1).

Table 1. 18S rRNA and psaB primer sequences

Table 1. 18S rRNA and psaB primer sequences

\begin{tabular}{|l|l|}
\hline 18S rRNA & Forward 5'- ATTGGAGGGCAAGTCTGGTG -3' \\
\hline 18SrRNAR & Reverse 5'- GTCCCACCCGAAATCCAACT -3' \\
\hline psaBF & Forward 5'-TGCCACTGGGTTTATGTTCC-3`' \\
\hline psaBR & Reverse 5`-GCCATCGTACGAGATTTGCT-3`' \\
\hline
\end{tabular}

RT-PCR is performed by using 2 XSYBR Green Kit (GMbiolab Co. Ltd., Taiwan) in $20 \mu 1$ reaction volume. Cycle Threshold (Ct) value was calculated based on Pfaffl (2004).

\section{Statistical Analysis}

All experiments were performed in 3 replicates. The data are presented as the mean \pm standard deviation of the mean (SDM). Spectrophotometrically obtained results and ICPMS results were supported by Freundlich (Freundlich, 1907) and Langmuir adsorption isotherms (Langmuir, 1916).

Cycle Threshold gene expression values obtained by RTPCR were calculated by SPSS 16.0 One-Way ANOVA test.

\section{Results and Discussion}

\section{Chlorophyll and Carbohydrate Contents}

Chl-a and b levels for the control group were measured 0.6812 and $0.2441 \mu \mathrm{g} / \mathrm{L}$ respectively. Since $10 \mathrm{mg} / \mathrm{L}$ is the highest concentration, chlorophyll level changes were observed most clearly for this concentration. Essential and non-essential metal treatments caused an increase in the chla levels. While chl-b levels were decreased with essential metal treatment except for $\mathrm{Mo}^{6+}$ and generally increased with non-essential metal treatment (Figure 1).

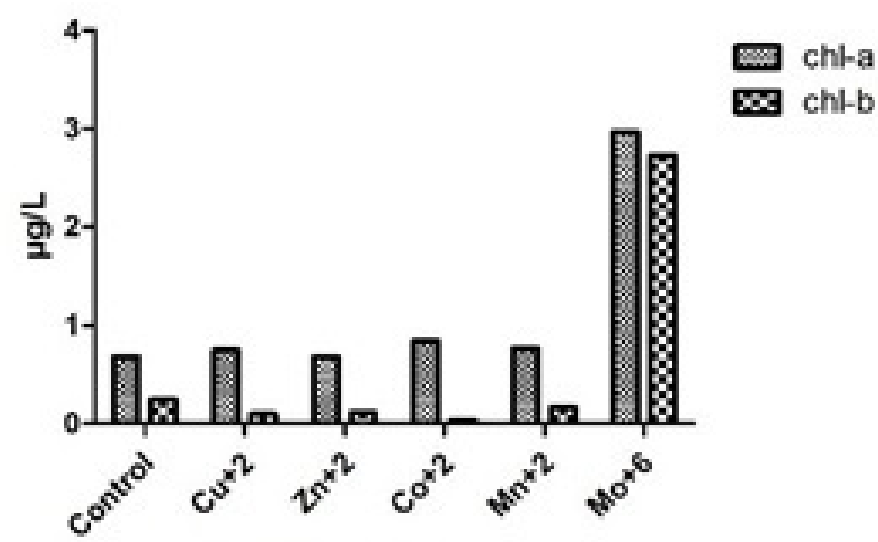

Essential metals

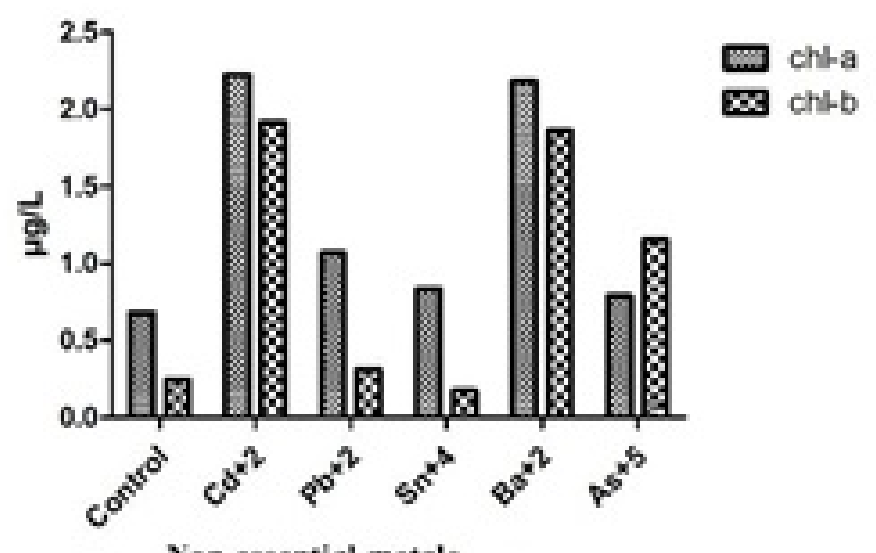

Figure 1. Chl-a and $\mathrm{b}$ changes in $\mu \mathrm{g} / \mathrm{L}$ after the essential and non-essential metal treatment

Carbohydrate content of the C. vulgaris samples were measured at $0.7035 \mathrm{mg} / \mathrm{mL}$ for the control group. Measurements for the carbohydrate content, metal concentration showed that $\mathrm{Zn}$ and $\mathrm{Cu}$ treatment causing an increase in carbohydrate levels. On the other hand carbohydrate content for Mn and As treatment measured as 0.4475 and $0.4492 \mathrm{mg} / \mathrm{mL}$, showing that these metals cause $63 \%$ of a decrease on the carbohydrate levels (Figure 2). 


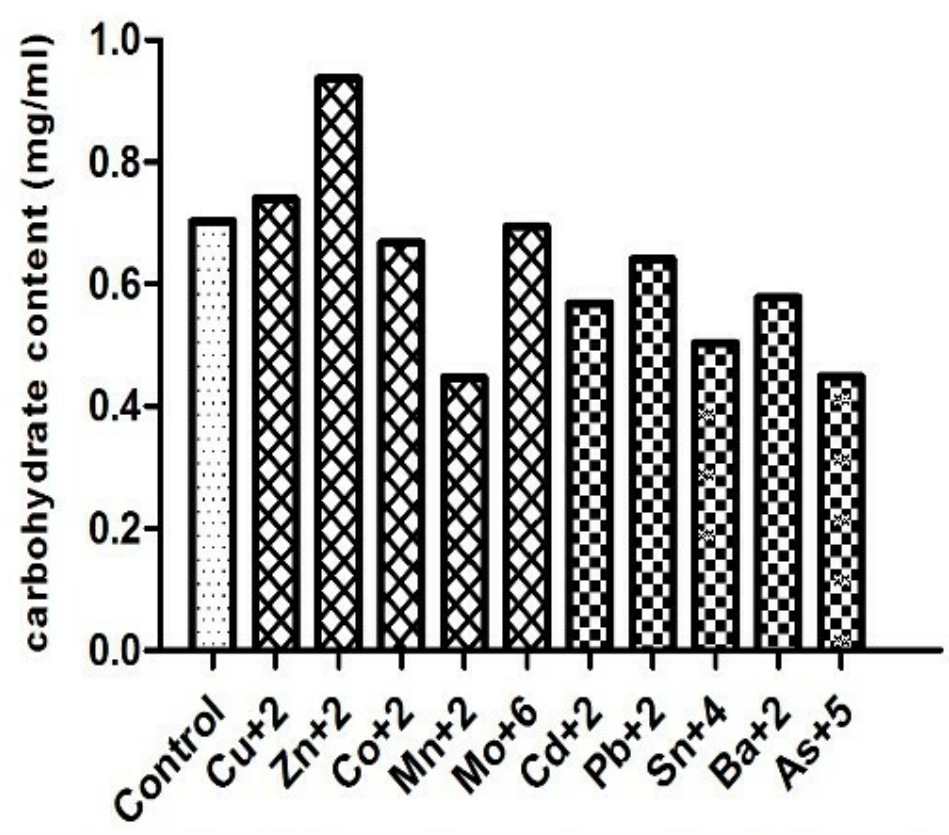

\begin{tabular}{|c|c|c|c|c|c|c|c|c|c|c|}
\hline Control & $\mathrm{Cu}$ & $\mathrm{Zn}$ & $\mathrm{Co}$ & $\mathrm{Mn}$ & $\mathrm{Mo}$ & $\mathrm{Cd}$ & $\mathrm{Pb}$ & $\mathrm{Sn}$ & $\mathrm{Ba}$ & $\mathrm{As}$ \\
\hline 0,7035 & 0,7402 & 0,937 & 0,6677 & 0,4475 & 0,694 & 0,5686 & 0,6406 & 0,5037 & 0,5785 & 0,4492 \\
\hline
\end{tabular}

Figure 2. Carbohydrate content changes in $\mathrm{mg} / \mathrm{mL}$ after the essential and non-essential metal treatment

\section{Metal Removal}

Metal removal results obtained from essential-metal treatment showed that average removal order was $\mathrm{Cu}>\mathrm{Co}>\mathrm{Zn}>$ $\mathrm{Mo}>\operatorname{Mn}(0.2483 ; 0.2482 ; 0.2442 ; 0.2374$ and $0.0820 \mathrm{mg} / \mathrm{g})$ respectively. For the non-essential metals average results obtained as $\mathrm{Sn}>\mathrm{Pb}>\mathrm{Ba}>\mathrm{Cd}>\mathrm{As}(0.2549 ; 0.2548 ; 0.2474$; 0.2463 and $0.2412 \mathrm{mg} / \mathrm{g}$ ) respectively (Table 2 ).

Metal removal capacity of $C$. vulgaris was also evaluated in $\mathrm{mg} / \mathrm{g}$ for all the metals separately for 5 different concentrations $(0.5 ; 1 ; 2.5 ; 5$ and $10 \mathrm{mg} / \mathrm{L})$. Lowest removal capacity was observed in Mn treatment (Figure 3).

\section{Gene Expression Analysis}

RT-PCR results indicated that essential metal treatment $(1.0,2.5,5,10 \mathrm{mg} / \mathrm{L})$ increased the $\mathrm{psaB}$ expression as compared to the control group. Similarly, non-essential metal treatment $(0.5,1,2.5,5,10 \mathrm{mg} / \mathrm{L})$ also caused an in an increase in $\mathrm{psaB}$ expression in a dose-dependent manner (Figure 4).

\section{Statistical Results}

Metal removal capacity of the biomass was determined by using Freundlich and Langmuir isotherms (Freundlich, 1907; Langmuir, 1916) (Table 3).

Correlation coefficient constants $\left(\mathrm{K}_{\mathrm{L}}, \mathrm{K}_{\mathrm{f}}\right)$ of essential metal removal was determined as ranging between 0.029-1.767 and 0.121-2.761 respectively. Lowest and highest $\mathrm{q}_{\mathrm{m}}$ values (maximum adsorption capacity of the adsorbent) was observed as $1.767 \mathrm{mg} / \mathrm{g}$ for Co and $0.001 \mathrm{mg} / \mathrm{g}$ for Mn. Calculated results showed that $C$. vulgaris is an effective adsorbent for essential metals (Table 4).

Correlation coefficient constants $\left(\mathrm{K}_{\mathrm{L}}, \mathrm{K}_{\mathrm{f}}\right)$ of non-essential metal removal was determined as ranging between 0.868 43.088 and 0.3591-6.124 respectively. Lowest and highest $\mathrm{q}_{\mathrm{m}}$ values (maximum adsorption capacity of the adsorbent) was observed as $8.296 \mathrm{mg} / \mathrm{g}$ for $\mathrm{Pb}$ and $0.075 \mathrm{mg} / \mathrm{g}$ for $\mathrm{Cd}$. Calculated results showed that $C$. vulgaris is relatively less effective adsorbent for non-essential metals as compared to essential metals (Table 5). 
Table 2. Metal removal results for the essential and non-essential metal mix treatment $(\mathrm{mg} / \mathrm{g})$

C. vulgaris essential metal mix removal $(\mathrm{mg} / \mathrm{g})$

\begin{tabular}{llllll}
\hline $\mathrm{mg} / \mathrm{L}$ & $\mathrm{Cu}$ & $\mathrm{Zn}$ & $\mathrm{Co}$ & $\mathrm{Mn}$ & $\mathrm{Mo}$ \\
\hline 0.5 & 0.032 & 0.031 & 0.033 & 0.031 & 0.030 \\
1 & 0.065 & 0.063 & 0.066 & 0.058 & 0.061 \\
2.5 & 0.164 & 0.161 & 0.163 & 0.035 & 0.156 \\
5 & 0.327 & 0.323 & 0.328 & 0.037 & 0.313 \\
10 & 0.653 & 0.644 & 0.651 & 0.249 & 0.627 \\
average & $\mathbf{0 . 2 4 8 3}$ & $\mathbf{0 . 2 4 4 2}$ & $\mathbf{0 . 2 4 8 2}$ & $\mathbf{0 . 0 8 2}$ & $\mathbf{0 . 2 3 7 5}$ \\
\hline & $\boldsymbol{C .}$ vulgaris non-essential metal mix removal (mg/g) & & & \\
\hline mg/L & $\mathrm{Cd}$ & $\mathrm{Pb}$ & $\mathrm{Sn}$ & $\mathrm{Ba}$ & $\mathrm{As}$ \\
\hline 0.5 & 0.032 & 0.033 & 0.033 & 0.033 & 0.032 \\
1 & 0.065 & 0.067 & 0.067 & 0.066 & 0.064 \\
2.5 & 0.162 & 0.168 & 0.168 & 0.163 & 0.161 \\
5 & 0.323 & 0.335 & 0.335 & 0.326 & 0.318 \\
10 & 0.649 & 0.671 & 0.671 & 0.649 & 0.631 \\
average & $\mathbf{0 . 2 4 6 3}$ & $\mathbf{0 . 2 5 4 7 9}$ & $\mathbf{0 . 2 5 4 8 5}$ & $\mathbf{0 . 2 4 7 4}$ & $\mathbf{0 . 2 4 1 2}$ \\
\hline
\end{tabular}

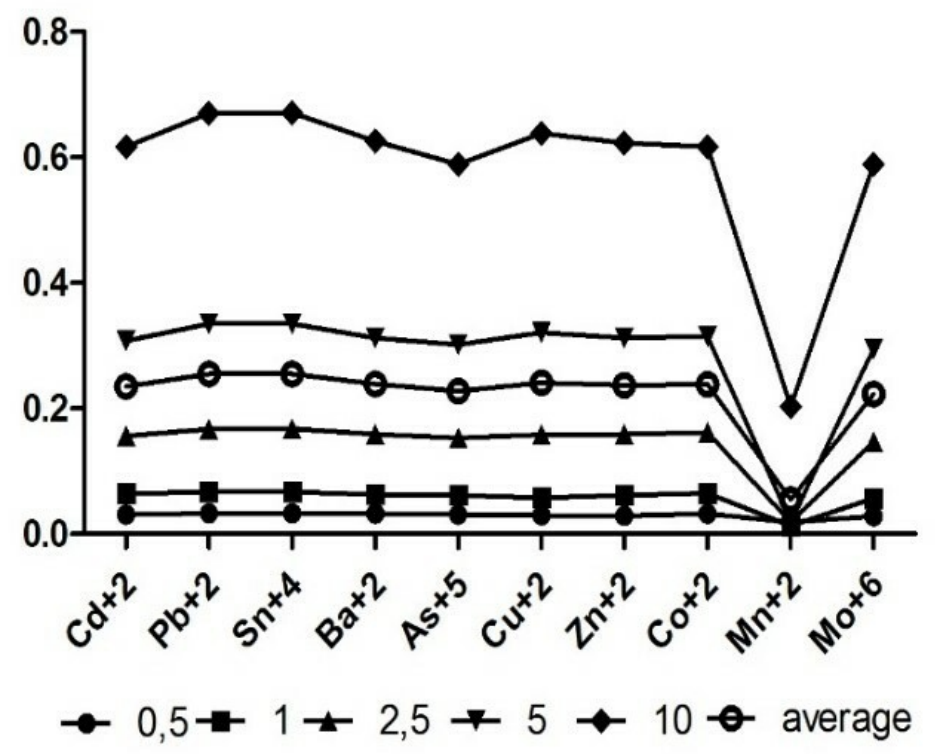

Figure 3. Metal removal levels measured for $0.5 ; 1 ; 2.5 ; 5$ and $10 \mathrm{mg} / \mathrm{L}$ and average values 


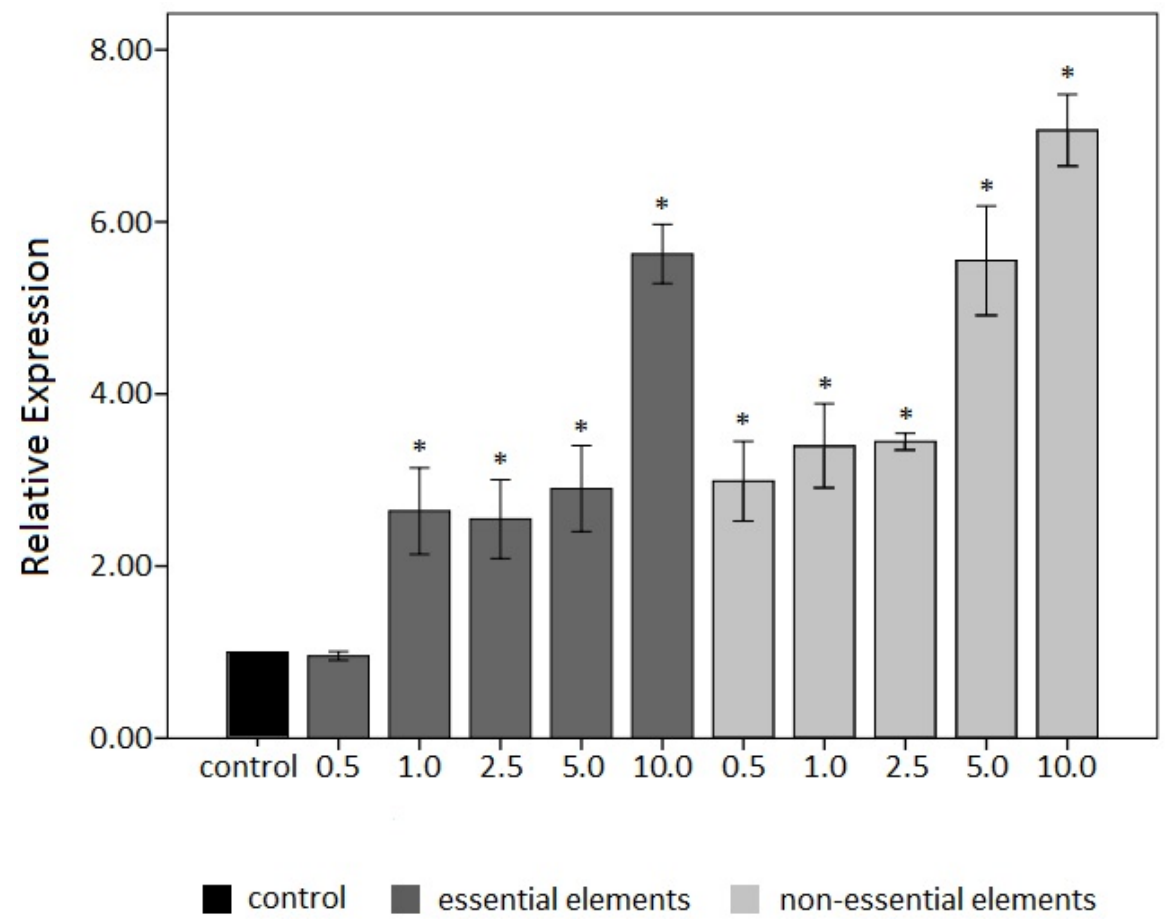

Figure 4.Relative expression changes of psaB mRNA values (fold change) of essential and non-essential heavy metal (0.5-10 $\mathrm{mg} / \mathrm{L}$ ) treated $C$. vulgaris cells according to the control cells. Error bars indicate the standard errors. Asterisk indicates significant differences $(* \mathrm{p}<0.01-0.001)$

Table 3. Langmuir and Freundlich isotherm models

Langmuir: $\mathrm{q}_{\mathrm{e}}=\left(\mathrm{K}_{\mathrm{L}} \cdot \mathrm{C}_{\mathrm{e}}\right) /\left(1+\mathrm{K}_{\mathrm{L}} \cdot \mathrm{C}_{\mathrm{e}}\right)$

Freundlich: $\operatorname{Inq}_{\mathrm{e}}=\operatorname{InK}_{\mathrm{F}}+1 / \mathrm{n} * \mathrm{InC}_{\mathrm{e}}$

Table 4. Adsorption isotherm constant for essential metals

\begin{tabular}{lrrrcc}
\hline & $\mathbf{C u}$ & $\mathbf{Z n}$ & $\mathbf{C o}$ & Mn & Mo \\
\hline Langmuir & & & & & \\
$\mathbf{q}_{\mathbf{m}}(\mathbf{m g} / \mathbf{g})$ & 1.3549 & 0.2382 & 1.6610 & 0.0011 & 0.2035 \\
$\mathbf{K}_{\mathbf{L}}(\mathbf{L} / \mathbf{m g})$ & 0.6443 & 0.7986 & 1.7671 & 0.0292 & 0.3924 \\
$\mathbf{R}^{\mathbf{2}}$ & 0.5635 & 0.0548 & 0.6664 & 0.0618 & 0.5340 \\
\hline Freundlich & & & & & \\
$\mathbf{n}(\mathbf{g} / \mathbf{L})$ & 0.6317 & 0.8381 & 1.2315 & 0.4381 & 0.7859 \\
$\mathbf{K}_{\mathbf{F}}(\mathbf{L} / \mathbf{m g})$ & 0.5908 & 0.1214 & 0.1862 & 2.7618 & 0.3234 \\
$\mathbf{R}^{\mathbf{2}}$ & 0.9102 & 0.9405 & 0.9676 & 0.4919 & 0.9921 \\
\hline
\end{tabular}


Table 5. Adsorption isotherm constant for non-essential metals

\begin{tabular}{lccccc}
\hline & $\mathbf{C d}$ & $\mathbf{P b}$ & $\mathbf{S n}$ & $\mathbf{B a}$ & As \\
\hline Langmuir & & & & & \\
$\mathbf{q}_{\mathbf{m}}(\mathbf{m g} / \mathbf{g})$ & 0.0758 & 8.296 & 7.820 & 0.8453 & 0.7154 \\
$\mathbf{K}_{\mathbf{L}}(\mathbf{L} / \mathbf{m g})$ & 1.1558 & 31.492 & 96.384 & 1.359 & 0.8687 \\
$\mathbf{R}^{\mathbf{2}}$ & 0.2967 & 0.1126 & 0.001 & 0.4978 & 0.8904 \\
\hline Freundlich & & & & & \\
$\mathbf{n}(\mathbf{g} / \mathbf{L})$ & 1.1500 & 0.9619 & 0.2700 & 1.1712 & 1.1075 \\
$\mathbf{K}_{\mathbf{F}}(\mathbf{L} / \mathbf{m g})$ & 0.3591 & 3.5704 & 6.1240 & 0.2086 & 0.5051 \\
$\mathbf{R}^{\mathbf{2}}$ & 0.9698 & 0.9715 & 0.7330 & 0.9920 & 0.9944 \\
\hline
\end{tabular}

Heavy metals are the crucial pollutants of the water environment. Algal populations hold great potential for monitoring and reducing the metal pollution due to their metal holding capacity (Çetinkaya et al., 1999). In order to understand and use algal populations for metal pollution, it is crucial to understand metal uptake mechanisms and its effects on algae.

In this study, $C$. vulgaris was used for understanding the metal removal capacity of the organism as well as the effects of removal. Remediation capacity, changes in chl-a, chl-b and carbohydrate contents and the photosynthetic gene expression levels were observed in C. vulgaris in the presence of essential and non-essential metals.

It has been showed that photosynthesis is relatively more vulnerable to metal toxicity as compared to other processes in algae (Lu et al., 2000). Metals can affect the photosynthesis by directly affecting the photosynthetic pathways, ion distribution, and enzyme activity disruption or via affecting the membrane permeability (Rai at al., 1981). Chlorophyll content results showed that metal treatment caused an increase in chl-a levels, while chl-b content decreased in essential metal treatment except for Mo, and increased in nonessential metal treatment except $\mathrm{Sn}$. These results indicated that while non-essential metals could be relatively tolerated, non-essential metals affects the chl-b content negatively. Heavy metals are known to affect chlorophyll pigment biosynthesis and enzymes adversely (Shioi et al., 1978). Observed changes in chl-a and $b$ contents also shows that photosynthetic pigment processes work mutually. The total carbohydrate content of $C$. vulgaris was measured lowest for Mn and As treatment (63.61\% and 63.58\% respectively).
These results can be explained by the fact that metal pollution causing the algal growth inhibition though affecting the necessary element uptake (Shioi et al., 1978; Gaur, \& Kumar, 1981; Lu et al., 2000; Bajguz, 2011).

Remediation efficiency of $C$. vulgaris was observed as $\mathrm{Cu}>\mathrm{Co}>\mathrm{Zn}>\mathrm{Mo}>\mathrm{Mn}$ for essential metals and $\mathrm{Sn}>\mathrm{Pb}>\mathrm{Ba}>\mathrm{Cd}>\mathrm{As}$ for non-essential metals. Low levels of biorption for Mn and As can be explained by the toxic effect of these metals on $C$. vulgaris, and shows consistency with total carbohydrate results. Highest uptake level was observed for $\mathrm{Cu}$. Related conducted studies was also showed that $C$. vulgaris has a high capacity of $\mathrm{Cu}$ uptake and store $\mathrm{Cu}$ through specific metal binding proteins (Rachlin \& Grosso, 1993; Knauer et al., 1997; Lopez et al., 2000; Soldo et al., 2005).

Gene expression levels of psaB for $0.5 \mathrm{mg} / \mathrm{L}$ essential metal treatment did not show a significant increase of the psaB relative expression level $(0.95)(p>0.05)$ compared to the control group. On the other hand, other concentrations of essential $(1.0,2.5,5.0,10.0 \mathrm{mg} / \mathrm{L})$ and non-essential $(0.5,1.0,2.5$, $5.0,10.0 \mathrm{mg} / \mathrm{L}$ ) metals caused increasing in the relative expression level of the psaB gene. $1.0,2.5,5.0,10.0 \mathrm{mg} / \mathrm{L}$ essential metal treatment increased the expression level of the psaB gene as a 2.6, 2.5, 2.9, 5.6, respectively, compared to the control group $(\mathrm{p}<0.001)$. Also, $0.5,1.0,2.5,5.0,10.0$ $\mathrm{mg} / \mathrm{L}$ non-essential metal treatment increased the expression level of the psaB gene as a 3.0, 3.4, 3.4, 5.4, 7.0, respectively, compared to the control group $(\mathrm{p}<0.001)$. This result could be explained by the fact that, most of these metals act as cofactors for metalloproteins and plays role in photosyn- 
thetic electron transport, respiration, and cell wall metabolism in small doses (Fayed et al., 1983). Metals like $\mathrm{Cu}$ and $\mathrm{Zn}$ takes part in oxidoreduction reactions as catalyzers for ROS. Thus, in high doses even the essential metals leads a toxic effect and decreases psbA gene expression level (responsible from the expression of D1 protein of the photosystem II (PSII)) while increases the psaB expression level (responsible from the expression of P700 chlorophyll A2 apoprotein of photosystem I (PSI)) (Raven et al., 1999; Mediouni et al., 2006). On the other hand, since non-essential metals do not take part in cell functions, they show a toxic effect even at the low doses (Qian et al., 2009). Results of the study showed that psaB expression levels increased with the essential and non-essential metal treatment. Considering the fact that psaB expression is related to $\mathrm{P} 700$ chlorophyll A2 apoprotein of photosystem I (PSI), obtained results related to the gene expression level showed consistency with the chlorophyll-a analysis results.

\section{Conclusion}

To conclude, this report describes the metal removal efficiency of $C$. vulgaris while illustrating the effect of essential and non-essential metals on carbohydrate and chlorophyll content as well as its relation between photosynthetic gene expression levels. Results indicate that $C$. vulgaris can be used as a bioindicator for $\mathrm{Mn}$ and $\mathrm{As}$ and it is also suitable to be used for metal removal from the polluted water environments.

\section{Compliance with Ethical Standard}

Conflict of interests: The authors declare that for this article they have no actual, potential or perceived conflict of interests.

Financial disclosure: This research was funded by the Manisa Celal Bayar University Scientific Investigation Project, Grant Nr. FEF 2015-154.

\section{References}

Aranda, P.S., LaJoie, D.M., Jorcyk, C.L. (2012). Bleach Gel: A simple agarose gel for analyzing RNA quality. Electrophoresis. 33(2), 366-369.

Bajguz, A. (2011). Suppression of Chlorella vulgaris growth by cadmium, lead, and copper stress and its restoration by endogenous brassinolide. Archives of Environmental Contamination and Toxicology, 60(3), 406-416.
Çetinkaya, Dönmez, G., Aksu, Z., Öztürk, A., Kutsal, T. (1999). A comparative study on heavy metal biosorption characteristics of some algae. Process Biochemistry, 34(1), 885-892.

De Philippis, R., Paperi, R., Sili, C. (2007). Heavy metal sorption by released polysaccharides and whole cultures of two exopolysaccharide-producing cyanobacteria. Biodegradation, 18(2), 181-187.

Fayed, S.E., Abdel-Shafy, H.I., Khalifa, N.M. (1983). Accumulation of $\mathrm{Cu}, \mathrm{Zn}, \mathrm{Cd}$, and $\mathrm{Pb}$ by Scenedesmus obliquus under nongrowth conditions. Environment International, 9(5), 409-413.

Franklin, N.M., Stauber, J.L., Markich, S.J., Lim, R.P. (2000). pH-dependent toxicity of copper and uranium to a tropical freshwater alga (Chlorella sp.). Aquatic Toxicology, 48(2-3), 275-289.

Freundlich, H. (1907). Über die adsorption in lösungen. Zeitschrift Für Physikalische Chemie, 57(1), 385-470.

Hong, K.S., Lee, H.M., Bae, J.S., Ha, M.G., Jin, J.S., Hong, T.E., Kim, J.P., Jeong, E.D. (2011). Removal of heavy metal ions by using calcium carbonate extracted from starfish treated by protease and amylase. Journal of Analytical Science and Technology, 2(2), 75-82.

Islam, E., Yang, X.E., He, Z.L., Mahmood, Q. (2007). Assessing potential dietary toxicity of heavy metals in selected vegetables and food crops. Journal of Zhejiang University-Science B, 8(1), 1-13.

Khan, M.A., Rao, R.A.K., Ajmal, M. (2008). Heavy metal pollution and its control through nonconventional adsorbents (1998-2007): a review. Journal of International Environmental Application and Science, 3(2), 101-141.

Knauer, K., Behra, R., \& Sigg, L. (1997). Effects of free $\mathrm{cu}^{2+}$ and $\mathrm{zn}^{2+}$ ions on growth and metal accumulation in freshwater algae. Environmental Toxicology and Chemistry, 16(2), 220-229.

König-Peter, A., Ferenc, K., Felinger, A., Pernyeszi, T. (2015). Biosorption characteristics of Spirulina and Chlorella cells for the accumulation of heavy metals. Journal of the Serbian Chemical Society, 80(3), 407419.

Langmuir, I. (1916). The constitution and fundamental properties of solids and liquids. Part I. Solids. Journal of 
the American Chemical Society. 1916, 38(11), 22212295.

López-Suárez, C., Castro-Romero, J., González-Rodríguez, M., González-Soto, E., Pérez-Iglesias, J., Seco-Lago, H.M., Fernández-Solís, J.M. (2000). Study of the parameters affecting the binding of metals in solution by Chlorella vulgaris. Talanta, 50(6), 1313-1318.

Lu, C., Chau, C., Zhang, J. (2000). Acute toxicity of excess mercury on the photosynthetic performance of Cyanobacterium, $S$. platensis - assessment by chlorophyll fluorescence analysis. Chemosphere, 41(12), 191-196.

Mediouni, C., Benzarti, O., Tray, B., Habib Ghorbel, M., Jemal, F. (2006). Cadmium and Copper Toxicity for Tomato Seedlings, EDP Sci. Agronomy for Sustainable Development. 26(4), 227-232.

Mehta, S.K., Gaur, J.P. (2005). Use of algae for removing heavy metal ions from wastewater: progress and prospects. Critical Reviews Biotechnology, 25(3), 113152.

Parsons, T.R., Strickland, J.D.H. (1965). Discussion of spectrophotometric determination of marine plant pigments, with revised equations for ascertaining chlorophylls and carotenoids. Journal of Marine Research, 21(2), 155-163.

Pfaffl, M.W. (2004). Quantification Strategies in Real-Time PCR Content of Chapter 3: Quantification Strategies in Real-Time PCR, In: In A-Z of Quantitative PCR. Bustin Press., California, USA., 89-112 pp.

Provasoli, L. (1958). Nutrition and ecology of protozoa and algae. Annual Review of Microbiology, 12(1), 279-308.

Qian, H., Li, J., Sun, L., Chen, W., Sheng, G.D, Liu, W., Fu, Z. (2009). Combined effect of copper and cadmium on chlorella vulgaris growth and photosynthesis-related gene transcription. Aquatic Toxicology, 94(1), 56-61.
Rai, L.C., Gaur, J.P., Kumar, H.D. (1981). Phycology and heavy-metal pollution. Biologycal Reviews, 56(2), 99151.

Rachlin, J.W., Grosso, A. (1993). The growth response of the green alga Chlorella vulgaris to combined divalent cation exposure. Archives of Environmental Contamination and Toxicology, 24(1), 16-20.

Raven, J.A., Evans, M.C.W., Korb, R.E. (1999). The role of trace metals in photosynthetic electron transport in $\mathrm{O}_{2}-$ evolving organisms. Photosynthesis Research, 60(2), 111-150.

Shioi, Y., Tamai, H., Sasa, T. (1978). Inhibition of photosystem II in the green alga Ankistrodesmus falcatus by copper. Physiology Plantarum, 44(4), 434438.

Skoog, D., Holler, F., Nieman, T., Kılıç, E., Köseoğlu, F. (2000). Enstrümantal Analiz ilkeleri. Ankara, Turkey, Bilim Press., 1038 pp.

Soldo, D., Hari, R., Sigg, L., Behra, R. (2005). Tolerance of Oocystis nephrocytioides to copper: Intracellular distribution and extracellular complexation of copper. Aquatic Toxicology, 71(4), 307-317.

Stanier, R.Y., Deruelles, J., Rippka, R., Herdman, M., Waterbury, J.B. (1979). Generic assignments, strain histories and properties of pure cultures of cyanobacteria. Microbiology. 111(1), 1-61.

Suresh Kumar, K., Hans-Uwe, D., Eun-Ji, W., Jae-Seong, L., Kyung- Hoon, S. (2015). Microalgae - a promising tool for heavy metal remediation. Ecotoxicology and Environmental Safety, 113(1), 329-352.

Wang, J., Chen, C. (2009). Biosorbents for Heavy Metals Removal and Their Future. Biotechnology Advances, 27, 195-226. 